\title{
The Impact of Employment Quality and Housing Quality on Human Development in the European Union
}

\author{
Marina Checa-Olivas ${ }^{1, *(D)}$, Bladimir de la Hoz-Rosales ${ }^{2}(\mathbb{D})$ and Rafael Cano-Guervos ${ }^{3}(\mathbb{D}$ \\ 1 Department of Financial Economics and Accounting, University of Cadiz, 11003 Cadiz, Spain \\ 2 Economics Programme, University of Magdalena, Santa Marta 470004, Colombia; \\ bdelahoz@unimagdalena.edu.co \\ 3 Department of Quantitative Methods for Economics and Business, University of Granada, \\ 18070 Granada, Spain; rcano@ugr.es \\ * Correspondence: mcheca@ugr.es
}

check for

updates

Citation: Checa-Olivas, M.; de la Hoz-Rosales, B.; Cano-Guervos, R. The Impact of Employment Quality and Housing Quality on Human Development in the European Union. Sustainability 2021, 13, 969. https://doi.org/10.3390/su13020969

Received: 23 December 2020

Accepted: 14 January 2021

Published: 19 January 2021

Publisher's Note: MDPI stays neutral with regard to jurisdictional claims in published maps and institutional affiliations.

Copyright: (c) 2021 by the authors. Licensee MDPI, Basel, Switzerland. This article is an open access article distributed under the terms and conditions of the Creative Commons Attribution (CC BY) license (https:// creativecommons.org/licenses/by/ $4.0 /)$.

\begin{abstract}
This study aims to contribute new information on how and through which factors employment quality and housing quality can be improved from a human development approach so that people can live the life they want. Using the human capabilities approach as a theoretical reference framework, the article analyses the effect of involuntary part-time employment and overcrowded housing on the Human Development Index (HDI). The empirical analysis is based on the panel data technique, which is applied to data from the European Statistical Office (Eurostat) and the United Nations Development Programme (UNDP) for the 28 member countries of the European Union. The results shed new evidence on how involuntary part-time work and overcrowded housing limit or hinder people from living the lives they want, at least in the dimensions measured by the HDI.
\end{abstract}

Keywords: human development; human capabilities approach; involuntary part-time work; overcrowding rate

\section{Introduction}

Since the 1950s, studies on the impact of employment on improving quality of life have mainly been aligned with theoretical approaches of economic growth [1] and have therefore mainly investigated the mechanisms that contribute to increasing economic income [2]. From the perspective of human development theories, however, research must be oriented towards how monetary income affects the expansion of capabilities so that people can do and be what they really want [3].

Similarly, from the perspective of the human development paradigm, the United Nations Development Programme (UNDP) emphasises the importance of providing real opportunities as a mechanism for people to access the labour market and achieve their life goals [4]. However, although public policies to support the creation of new jobs are based on UN recommendations, very few studies have provided insight into the determinants of employment quality [5,6], that is, the specific factors of labour market activity that would allow people to lead the lives they want. In this line of thought, Sehnbruch [7] argued that incorporating certain job quality indicators in the analysis of human development provides a broader vision of the labour market and a better explanation of the capabilities and functionings generated by employment.

Investigations have identified housing as one of the key socioeconomic indicators for evaluating quality of life [8-10]. Housing is a safe, physical space for families to coexist and transmit values and as such has become one of the basic goods to determine a society's welfare [11]. For this reason, several studies have argued that the capability to have a home should not be analysed only from the viewpoint of providing shelter, but that it is also necessary to identify the fundamental components of housing quality in order to determine people's well-being [12-15]. In other words, it is necessary to analyse the 
minimum housing conditions so that the members of a household can live the lives they truly desire.

In accordance with the above, the main objective of this study is to provide new information on how and through what elements the quality of employment and housing can be improved from the perspective of human development, so that people increase their capabilities. To this end, the human capabilities approach (HCA) is used as a theoretical reference framework and an empirical analysis is carried out to examine the impact of involuntary part-time employment and overcrowded housing on human development. The analysis is performed using European Statistical Office (Eurostat) and UNDP data for the 28 member countries of the European Union. The statistical information is processed and analysed using the panel data technique.

The paper is structured as follows. Section 2 presents the conceptual framework and the study hypotheses, as well as a description of the methodology and data. The results are analysed in Section 3. Section 4 contains the discussion. Finally, the conclusions and limitations of the study are presented in Section 5 .

\section{Hypotheses, Materials and Methods}

\subsection{Theoretical Framework and Hypotheses}

Historically, per capita GDP has been the macroeconomic indicator used to measure productivity and development [16]. However, it has become clear that in order to measure development from a multidimensional perspective, it is necessary to go beyond purely economic indicators [2]. Measuring development through variables such as per capita GDP or national wealth perpetuates the traditional approach that links development to economic growth and opulence [17], while development that seeks citizens' well-being must focus on the positive freedoms or capabilities of individuals [18].

The HCA, originally developed by Amartya Sen, is one of the most widely used approaches for measuring development and well-being from a multidimensional perspective [19]. As a result of Sen's contributions to the development of an alternative measure of quality of life to traditional well-being approaches, he is now considered one of the main theoreticians of human development [3]. The HCA expands on the concept of wealth to evaluate what people are capable of doing or being.

Three key concepts are central to the notion of the HCA: capabilities, agency and functionings $[3,20,21]$. Capabilities are what people have the freedom to do and agency is the ability of people to pursue the goals they have voluntarily set for themselves (i.e., people lack agency when they engage in compulsory activities) [22], while functionings are understood as what people can actually do or be [23]. Functionings are analysed from a normative perspective; but in light of this, the HCA suggests that their neutrality be recognised. According to Robeyns [3], functionings are constitutive elements of human life that can produce both well-being and ill-being. Therefore, the notion of functionings should be defined as a value-neutral category in the sense of an action to produce outcomes about which society makes value judgments as to their appropriateness. Thus, when analysing labour market activities, the action of working as a functioning will be associated with a positive, negative or simply trivial value for the person who performs the activities or for society [24].

Understanding functionings as activities that are actually performed and capabilities as the freedoms to achieve these functionings allows us to distinguish the dimensions in which interpersonal comparisons of advantages are made, which constitute one of the most important aspects of human capabilities-based analyses [3]. Similarly, while functionings are universal or constitutive of human life, some actions or events may not be constitutive but rather dependent on social structures, what are known as "contextdependent functionings" [3]. In line with the above, and for purposes of analysis, since the action of being employed in the world of work is a human activity, it is a functioning.

Sen [25] states that through work and income, functionings, capabilities and, ultimately, utility are generated for the employed person. However, a true application of 
the capabilities approach to employment involves recognising the factors that influence the individual's ability to convert the characteristics of a given job into a set of attainable functionings [26,27]. Therefore, instead of considering only the quantity of employment, attention should be also paid to factors related to the quality of employment in order to truly determine the capabilities and well-being of individuals. In this regard, employment quality is an important explanatory factor for the capabilities and functionings that individuals can generate, since it takes into account what people can achieve with a given set of job characteristics [7].

Research has shown that involuntary part-time work is a key indicator of employment quality as this type of work has certain characteristics that influence the well-being of workers [6,28]. According to the International Labour Organization (ILO), there are various kinds of employment depending on the type of authority, the type of economic risk, the duration of the work agreement, the type of work agreement, forms of remuneration or the place of work [29]. However, there are common elements in these definitions which indicate that a worker is a person who performs a set of human activities to produce goods or services in an economy or who meets the needs of a community and provides the necessary means of support for individuals [29]. Therefore, the action of working is a functioning that depends both on the skills and abilities of the person who performs the work and on the social and institutional circumstances in which the work activity is carried out; in other words, the action of working is a context-dependent functioning.

A second analysis of work as a functioning involves recognising its neutrality; that is, the action of being employed does not depend on the impact of the activity on society, but on the certainty that a person has performed the action of creating goods or services. Once such an action is materialised, the person who performs it and society will make value judgements as to its appropriateness. Thus, when the action of working is identified as a neutral functioning, it is possible to study the action from a normative point of view, which implies making value judgments about whether something is better or worse than something else. Alkire [22] described the HCA as a proposition for evaluating social arrangements according to the degree of freedom people have to promote or achieve the functionings they value. Robeyns [3], however, argues that if functionings can be valued positively or negatively, then we must acknowledge that people's lives are better if they contain fewer of the functionings that are valued negatively, such as physical violence or stress. Thus, for Robeyns, Alkire's proposal should be extended by adding at the end "and to promote the weakening of those functions that have a negative value."

Thus, when introducing the normative aspect into the action of working, this human activity should be viewed as a refined functioning, that is, one that is chosen from among a set of possibilities [30]. In this sense, it can be inferred that, in the framework of the HCA, work that enables people to lead the life they really want must have the characteristics of a refined functioning [3]. Similarly, the outcome of the work, in addition to benefiting the worker, must be positive for society, thus facilitating the realisation of functionings and expanding the capabilities of other people.

In practice, the European Commission measures and monitors the different types of labour in the European Union mainly through the Eurostat. This organisation classifies employment according to working time. Under this classification, involuntary part-time work is defined as work performed by workers as a result of not having been able to find a full-time job despite their desire to do so [31]. In acknowledging the conceptual neutrality of functionings, it is possible to state that involuntary part-time work constitutes a functioning because it denotes the performance of a human activity. However, from a normative standpoint, the evaluation of this functioning cannot go beyond its definition, that is, as a means of subsistence for the person performing it.

The results of studies that analyse the impact of some types of involuntary work, such as self-employment out of necessity, indicate that when people are forced to perform an economic activity as the only option for their survival, they have limited agency. This can lead to dissatisfaction with the activity, since there is no opportunity to exercise one's free 
will and choose what one would really like to do. A direct relationship has also been found between involuntary part-time work and working poverty, since these types of jobs are poorly paid and performed solely for purposes of subsistence $[6,28]$. This implies that it is a functioning which limits the agency of the person performing the job, because they do not have the freedom to choose the job they would like due to the lack of employment opportunities [28].

Therefore, it could be inferred that involuntary part-time work is an activity that involves an action and produces changes, but it makes it difficult for people to develop the life they really want. This brings us to our first hypothesis:

Hypothesis 1 (H1). Involuntary part-time work restricts the expansion of human capabilities for people to be able to lead the life they want.

On the other hand, capabilities can be measured by real access to the freedoms that allow people to achieve the lifestyle they desire. Similarly, freedoms are not only the primary ends of human development, but also part of its principal means [18]. In this regard, there is a long list of instrumental freedoms that help people improve their quality of life. In particular, political freedoms, economic facilities, social opportunities, transparency guarantees and protective security can be considered basic instrumental freedoms because they affect most aspects of people's decisions about how they want their lives to be [18].

As concerns the fundamental right of every person to have decent housing, this aspect is associated with instrumental freedoms related to social opportunities and protective security. The right to housing is enshrined in Article 25 of the Universal Declaration of Human Rights, making it a basic fundamental right or, in Sen's [18] words, an instrumental freedom that contributes directly to the "overall freedom people have to live the way they would like to live."

Numerous studies have identified housing as one of the fundamental elements of well-being [12-15]. Indeed, housing is a material dimension that determines the well-being of human beings, not only because it is the physical space where we live, but also because it is the place where people spend more than half of their daily lives. Therefore, the capability to have a home should not be interpreted only in the restrictive sense of providing shelter, but should be considered the right to live in decent or adequate housing. In this sense, the Office of the UN High Commissioner for Human Rights establishes that for housing to be considered adequate, it must meet at least the following criteria: security of tenure, housing quality in terms of the availability of basic public services, adequate space, affordability, habitability, accessibility to meet the specific needs of disadvantaged and marginalised groups and cultural adequacy [31].

Therefore, guaranteeing sufficient space is one of the basic characteristics for a home to be considered adequate. Some studies, such as those of Rindfuss et al. [32], Pan [33] and Kutty [34], indicate that overcrowding (lack of sufficient space within the home) is one of the fundamental elements for measuring housing quality. For its part, the European Commission [35] also considers the rate of overcrowding as one of the key indicators for measuring housing quality.

Thus, in addition to the capability to have a home, we incorporate the real freedom that a person has to access a decent home, that is, the minimum conditions that allow people to achieve their life expectations. In this sense, living in an overcrowded home adversely affects people's overall capabilities, as it restricts basic instrumental freedoms, particularly protective security. Therefore, living in overcrowded conditions influences human development, as inferred in the second hypothesis of this study:

Hypothesis 2 (H2). When people live in overcrowded conditions, their capability to do and be what they really want is restricted. 


\subsection{Materials}

\subsubsection{Dependent Variable}

Following the theoretical framework of Sen's approach, the UNDP adopted the human development concept in 1990, which is now measured globally by the Human Development Index (HDI) [36]. This index comprises three dimensions: a long and healthy life, knowledge and a decent standard of living [37]. Therefore, the HDI was used in this study as a dependent variable. Dhahri and Omri [37] also used the HDI to identify the contribution of entrepreneurship to sustainable development. The data for the HDI indicator were obtained from statistics provided by the United Nations.

\subsubsection{Independent Variables}

To analyse the effect of involuntary part-time work on an individual's human development, the rate of involuntary part-time employment (IPE) has been used. This variable is calculated as the proportion of workers who were unable to find full-time work over the total number of part-time workers. This variable has been used in numerous studies as an indicator to measure employment quality, as it is related to low-paying, low-productivity work, and also indicates the lack of suitable alternative employment opportunities [6,28].

To measure the effect of living in overcrowded conditions on an individual's human development, the variable overcrowding rate (OVER) was used. This variable has been used in numerous studies because it is considered one of the key dimensions for evaluating the quality of housing [32-34] and is calculated as the percentage of the population living in an overcrowded household. According to the Eurostat, a person is considered as living in an overcrowded household if the household does not have at its disposal a minimum number of rooms equal to: one room for the household; one room per couple in the household; one room for each single person aged 18 or more; one room per pair of single people of the same gender between 12 and 17 years of age; one room for each single person between 12 and 17 years of age and not included in the previous category; and one room per pair of children under 12 years of age [35].

In addition, two control variables have been used. The first control variable is employment rate (EMP), which is calculated as the percentage of employed persons aged 20 to 64 years over the total working-age population. EMP measures the employment supply or "job quantity" available in a given country. This variable is a key indicator of labour market development [6] and has been used to determine the impact of employment supply on economic growth [38]. The second control variable is migration rate (EMI), which is calculated as the percentage of migrants in relation to the country's total population. The data for these four indicators were obtained from the Eurostat statistical database.

\subsection{Methods}

The data for this study covered the 28 countries of the European Union for the period 2006-2018. When there is information over time in the same cross-sectional units, it is feasible to design models in which temporal and cross-sectional data are combined using the panel data technique [39]. One of the main advantages of this technique is the possibility of quantifying the time-invariant unobservable factors related to the cross-sectional units that influence the dependent variable [40-42].

To capture these factors related to the cross-sectional units, there are two types of specifications: the fixed effects (FE) model, which assumes that the original order changes constantly for each unit; and the random effects (RE) model, which assumes that the original order is formed by a constant and a random part [40]. However, before determining whether the FE or RE specification is more adequate, it is important to rule out a pooled model, which does not consider the presence of effects of the different units. The results of the Fand Breusch-Pagan tests indicated that the panel data technique was more suitable for this study than the pooled model estimated by the ordinary least squares method.

Moreover, the results of the Hausman test $[43,44]$ indicated that the FE model was more suitable than the RE model. Following Frank [45], we also applied the impact 
threshold for a confounding variable (ITCV) method to check that the regression analysis was not biased by unobservable variables that could have been omitted in the modelling process [46-48]. The ITCV test indicated that the results were reasonably robust to control for potential endogeneity.

Subsequent tests were performed to validate the Gauss-Markov assumptions on autocorrelated errors and the presence of heteroscedasticity. The Wooldridge test [40] indicated the existence of autocorrelation and the Wald modified test revealed the presence of heteroscedasticity. According to Canarella and Gasparyan [49], estimates made using panel data often present problems of heteroscedasticity, serial autocorrelation and contemporaneous autocorrelation. These problems arise when errors are dependent on the cross-sections in the panel data model [50] but can be solved by applying the feasible generalised least squares (FGLS) technique.

However, Beck and Katz [51] demonstrated that FGLS produces standard errors that are seriously underestimated. Moreover, the authors describe Monte Carlo experiments in which the evaluation of panel-corrected standard errors (PCSE) allows the correction of the presence of serial autocorrelation, heteroscedasticity and even contemporary correlation with precise evaluations of standard error, with little or no loss of efficiency as compared with FGLS. In this sense, PCSE estimation method rather than FGLS is more efficient to correct problems of serial autocorrelation, heteroscedasticity and contemporaneous correlation. In addition, PCSE has the advantage that it can be used when the length of the time series is less than the number of observations, which is the case of the data selected in this study. Therefore, the results of the evaluations correspond to PCSE, which is represented in the following equation:

$$
H D_{i t}=\beta_{0 i}+\beta_{1} I P E_{i t}+\beta_{2} O V E R_{i t}+\beta_{3} E M P_{i t}+\beta_{4} E M I_{i t}+\boldsymbol{e}_{i t}
$$

where $i$ is the $i$-th transversal unit (country); $t$ is the time (year); HDI is a variable measuring human development; IPE is a measure of involuntary part-time work; OVER measures the overcrowding rate; EMP measures the employment rate and EMI measures the percentage of migrants in a given country.

\section{Results}

Table 1 summarises the descriptive statistics of the variables. The secondary information used to empirically test the proposed hypotheses is the 28 countries that constituted the European Union for the 13 years under study, specifically the period 2006-2018. The table also shows the results of the correlation estimations between the variables under study, which are consistent with the theory, thus providing initial evidence in support of the proposed hypotheses. As can be observed, there is a negative and significant correlation between the variables HDI and IPE. Similarly, the correlation between HDI and OVER is negative and significant.

Table 1. Descriptive statistics and correlation matrix.

\begin{tabular}{cccccccccc}
\hline Variable & No & Mean & Std. Dev. & Min. & Max. & $\mathbf{1}$ & $\mathbf{2}$ & $\mathbf{3}$ \\
\hline 1. HDI & 364 & 86.41 & 4.03 & 75.6 & 94.2 & 1 & & \\
2. IPE & 364 & 29.52 & 17.59 & 5 & 72.6 & $-0.3535^{* * *}$ & 1 & \\
3. OVER & 364 & 20.70 & 17.26 & 1.4 & 60 & $-0.3595^{* * *}$ & $0.3219^{* * *}$ & 1 \\
4. EMP & 364 & 69.89 & 5.87 & 52.9 & 82.4 & $0.1500^{* *}$ & $-0.5329^{* * *}$ & $-0.3970 * * *$ & 1 \\
5. EMI & 364 & 0.72 & 0.53 & 0.03 & 2.91 & $0.0974^{*}$ & -0.0085 & $-0.2132^{* * *}-0.0100$ \\
\hline
\end{tabular}

Source: Own elaboration. Note. ${ }^{* * *} p<0.01$; $^{* *} p<0.05 ;{ }^{*} p<0.1$.

Figure 1 shows the spatial distribution of the average HDI and the involuntary parttime employment rate from 2006 to 2018 for the 28 countries of the European Union. As can be observed in the figure, countries with a high rate of involuntary part-time employment (dark blue shades), such as Romania, Bulgaria, the Czech Republic, Croatia, Cyprus, Poland 
and Portugal, also have a low HDI. Therefore, the information presented in the figure may provide initial evidence to support Hypothesis 1 of this paper, that is, the opposite relationship between IPE and HDI.

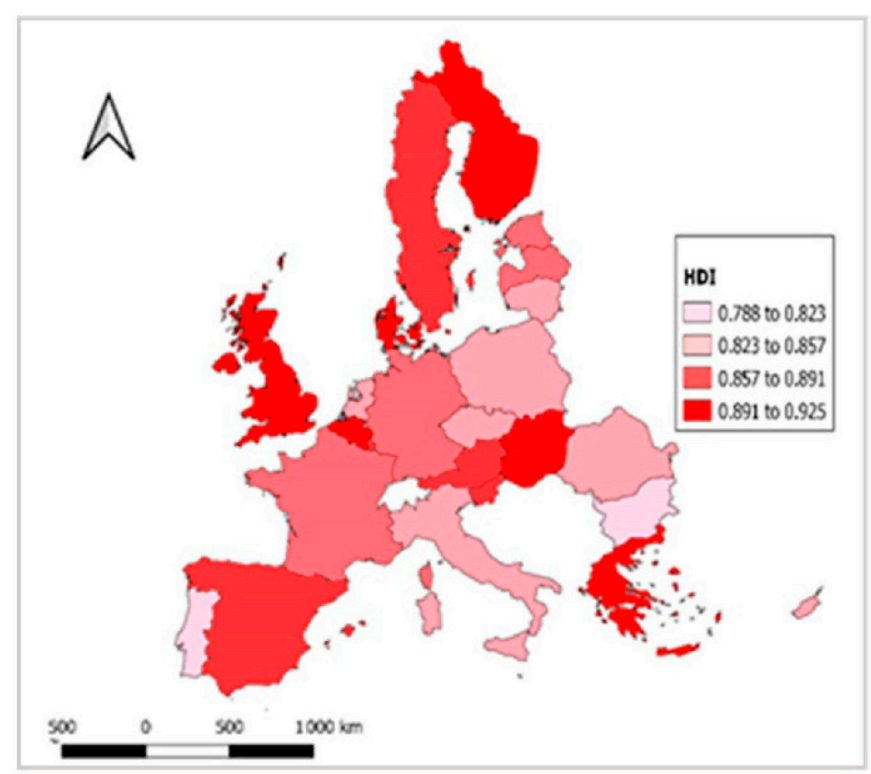

(a)

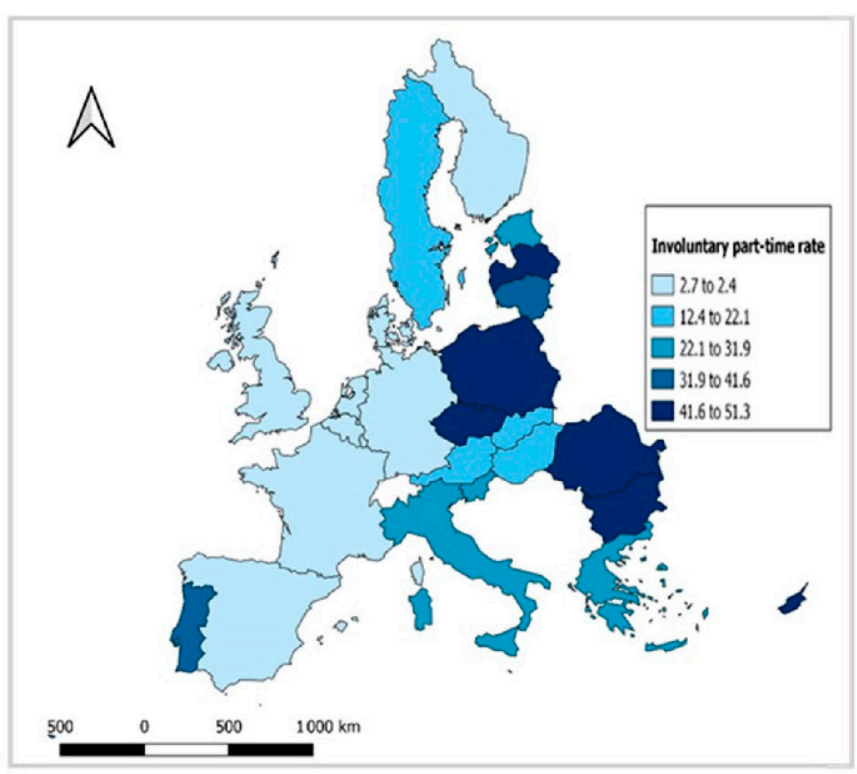

(b)

Figure 1. Spatial distribution of the average Human Development Index (HDI) (a) and of the involuntary part-time employment rate (b) in the EU countries. Source: Own elaboration based on Eurostat and UNDP data.

Figure 2 shows the spatial distribution of the average HDI and the overcrowding rate from 2006 to 2018 in the 28 countries. As can be seen, the countries with the highest overcrowding rate (dark blue shades), such as Romania, Bulgaria, the Czech Republic, Cyprus, Poland and Portugal, also have a low HDI. Therefore, the information presented in this figure indicates the existence of the opposite relationship between OVER and HDI established in Hypothesis 2.

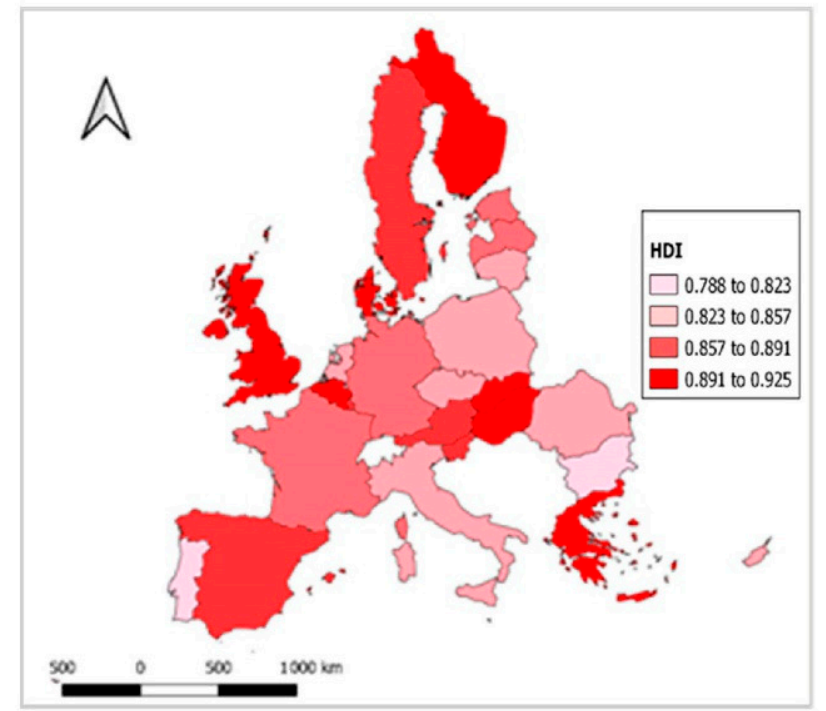

(a)

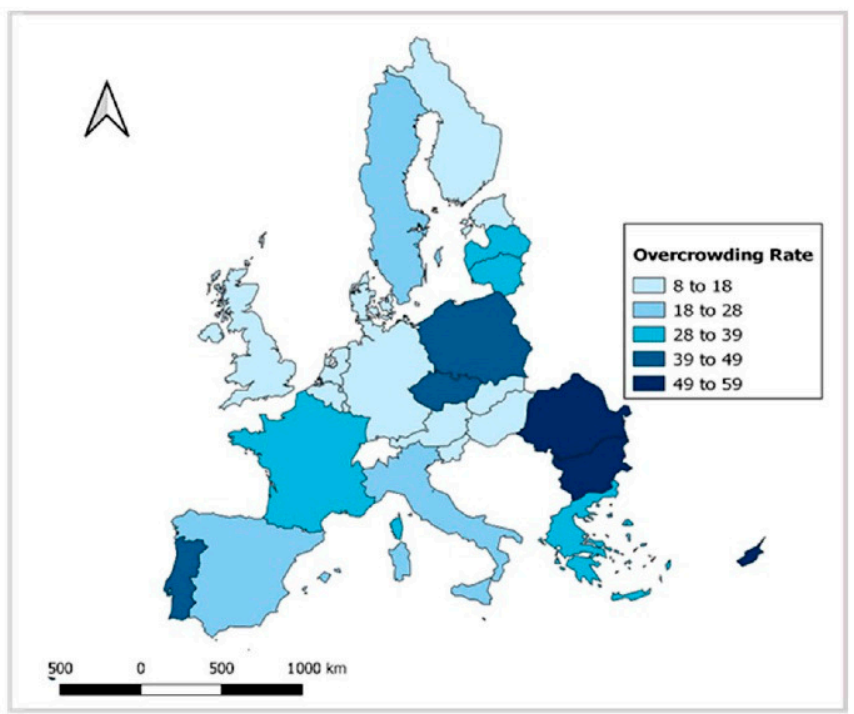

(b)

Figure 2. Spatial distribution of the average HDI (a) and of the overcrowding rate (b) in the EU countries. Source: Own elaboration based on EUROSTAT and UNDP data. 
Table 2 summarises the results of the PCSE regressions (models 3 and 4). Model 4 has been estimated as a measure of the robustness of the results obtained in Model 3 due to the addition of dichotomous temporal (Year) and spatial (Country) variables, which are significant and should therefore remain in the estimate. Overall, Model 4 is significant at $99 \%\left(\chi^{2}=1374, p<0.0001\right)$. Similarly, Model 4 shows that the relationship between IPE and human development in the countries of the European Union and over the period of time analysed is negative at a 95\% confidence level. Additionally, OVER displays a negative relationship with human development at a $99 \%$ confidence level in the countries of the European Union and over the time studied. Hence, Hypotheses 1 and 2 are validated.

Table 2. Regression analysis.

\begin{tabular}{|c|c|c|c|c|}
\hline & $\begin{array}{l}\text { Model } 1 \text { OLS } \\
\text { Pooled }\end{array}$ & $\begin{array}{l}\text { Model } 2 \\
\text { Fixed Efect }\end{array}$ & Model 3 PCSE & $\begin{array}{c}\text { Model } 4 \text { PCSE } \\
\text { (Controlled by Year and Country) }\end{array}$ \\
\hline Variable & & $H D I$ & & HDIM \\
\hline IPE & $\begin{array}{c}0.08^{* * *} \\
(0.01)\end{array}$ & $\begin{array}{c}0.09 * * * \\
(0.01)\end{array}$ & $\begin{array}{c}-0.02 * * \\
(0.01)\end{array}$ & $\begin{array}{c}-0.01 * * \\
(0.00)\end{array}$ \\
\hline OVER & $\begin{array}{c}-0.10^{* * *} \\
(0.01)\end{array}$ & $\begin{array}{c}-0.11^{* * *} \\
(0.01)\end{array}$ & $\begin{array}{c}-0.04^{* * *} \\
(0.00)\end{array}$ & $\begin{array}{c}-0.02^{* * *} \\
(0.00)\end{array}$ \\
\hline$E M P$ & $\begin{array}{l}0.22^{* * *} \\
(0.02)\end{array}$ & $\begin{array}{c}0.23^{* * *} \\
(0.02)\end{array}$ & $\begin{array}{c}0.63^{* * *} \\
(0.02)\end{array}$ & $\begin{array}{c}0.02 \\
(0.01)\end{array}$ \\
\hline$E M I$ & $\begin{array}{c}0.79 * * * \\
(0.00)\end{array}$ & $\begin{array}{c}0.74^{* * *} \\
(0.21)\end{array}$ & $\begin{array}{c}0.49^{* * *} \\
(0.18)\end{array}$ & $\begin{array}{c}0.06 \\
(0.09)\end{array}$ \\
\hline Time (Year) fixed effects & & & & $* * *$ \\
\hline Country fixed effects & & & & $* * *$ \\
\hline CONS & $\begin{array}{c}70.15^{* * *} \\
(1.79)\end{array}$ & $\begin{array}{l}69.34^{* * *} \\
(1.65)\end{array}$ & $\begin{array}{l}83.53^{* * *} \\
(1.97)\end{array}$ & $\begin{array}{l}87.34^{* * *} \\
(1.02)\end{array}$ \\
\hline $\mathrm{N}$ & 364 & 364 & 364 & 364 \\
\hline Groups & 28 & 28 & 28 & 28 \\
\hline Chi2 & $357.41 * * * *$ & & $56.67^{* * * *}$ & $1374^{* * * *}$ \\
\hline F Prob. & & 0.0001 & & \\
\hline
\end{tabular}

Note. $\left.{ }^{* * * *} p<0.001 ; * * *\right) p<0.01 ;{ }^{* *} p<0.05$. Standard errors in parentheses.

As indicated in Section 2.3, to check that the results of the regression analysis shown in Table 2 are not affected by a possible correlated-omitted-variable bias, an ITCV test was carried out. According to the test, the higher the ITCV value, the less likely it is that the regression results will be affected by a possible bias due to the omission of explanatory variables. Table 3 shows the results of the ITCV test for the regression when the omitted variable is IPE. As can be seen, none of the impacts of the other variables included in the regression model are greater (in absolute value) than the absolute value of ITCV, which is 0.3489 . Therefore, it is very unlikely that an omitted variable would have a higher correlation with the dependent variable HDI and with the independent variable IPE than any of the other correlated variables included in the model that would invalidate the result obtained for IPE. To ensure the robustness of the results to potential correlatedomitted variables, the same analysis was also performed using the ITCV test when the omitted variable is OVER (Table 4). As can be observed, the ITCV value is -0.4509 , which is a greater absolute value than all the absolute values for the impact of the remaining non-dependent variables of the regression model. The conclusions obtained from the application of the ITCV test strongly support the conclusion that the regression results are not affected by problems of potential endogeneity. 
Table 3. Impact threshold for a confounding variable for the test of the association between IPE and HDI.

\begin{tabular}{ccccccccc}
\hline Variables & $\mathbf{( 1 )}$ & $\mathbf{( 2 )}$ & $\mathbf{( 3 )}$ & $\mathbf{( 4 )}$ & $\mathbf{( 5 )}$ & $\mathbf{( 6 )}$ & $\mathbf{( 7 )}$ & $\mathbf{( 8 )}$ \\
\hline & ITCV & $\begin{array}{c}\text { ITCV Implied } \\
\text { Correlations }\end{array}$ & Cor(X,IPE) & Cor(X,HDI) & Impact & Cor(X,IPE) & Cor(X,HDI) & Impact ${ }_{\text {raw }}$ \\
\hline IPE & 0.3489 & 0.591 & & & & & & \\
OVER & & & 0.1417 & -0.3172 & -0.45 & 0.3219 & -0.3595 & -0.1157 \\
EMP & & & -0.4629 & 0.0111 & -0.0051 & -0.5329 & 0.1500 & -0.0800 \\
EMI & & & 0.0158 & 0.0239 & 0.0004 & -0.0085 & 0.0974 & -0.0008 \\
\hline
\end{tabular}

Source: Own elaboration. Notes: Table 3 shows the impact of the possible correlated-omitted variables on the results for the multivariate test of the association between the rate of involuntary part-time employment (IPE) and HDI. The results of the impact threshold for a confounding variable (ITCV) test are also shown. Column (1) indicates the ITCV, which is the lowest product of the partial correlation between the dependent variable HDI and the confounding variable and the partial correlation between the key independent variable IPE and the confounding variable that makes the IPE coefficient statistically insignificant. Column (2) indicates the implied minimum correlation that a confounding variable must have with the dependent variable HDI and with IPE to make the IPE coefficient statistically insignificant. Column (3) shows the partial correlations between IPE and each of the other independent variables of the regression model. Column (4) shows the partial correlations between the dependent variable HDI and each of the independent variables of the regression model (excluding IPE). Column (5) shows the partial impact of each independent variable (excluding IPE), which is obtained as the product of the two partial correlations shown in Columns (3) and (4). Column (6) shows the raw correlations between IPE and each of the other independent variables in the regression model. Column (7) shows the raw correlations between the dependent variable HDI and each of the independent variables of the regression model (excluding IPE). Column (8) shows the raw impact of each independent variable (excluding IPE), which is obtained as the product of the two raw correlations shown in Columns (6) and (7).

Table 4. Impact threshold for a confounding variable for the test of the association between OVER and HDI.

\begin{tabular}{ccccccccc}
\hline Variables & $\mathbf{( 1 )}$ & $\mathbf{( 2 )}$ & $\mathbf{( 3 )}$ & $\mathbf{( 4 )}$ & $\mathbf{( 5 )}$ & $\mathbf{( 6 )}$ & $\mathbf{( 7 )}$ & $\mathbf{( 8 )}$ \\
\hline & ITCV & $\begin{array}{c}\text { ITCV Implied } \\
\text { Correlations }\end{array}$ & Cor(X,OVER) & Cor(X,HDI) & Impact & Cor(X,OVER) & Cor(X,HDI) & Impact $r$, \\
& & 0.672 & & & & & & \\
OVER & -0.4509 & & 0.1417 & -0.3269 & -0.0463 & 0.3219 & -0.3535 & -0.1138 \\
IPE & & & -0.2936 & -0.0466 & 0.0137 & -0.3970 & 0.1500 & -0.0596 \\
EMP & & & -0.238 & 0.1000 & -0.0238 & -0.2132 & 0.0974 & -0.0208 \\
EMI & & & &
\end{tabular}

Source: Own elaboration. Notes: The table shows the impact of the possible correlated-omitted variables on the results for the multivariate test of the association between overcrowding rate (OVER) and HDI. The results of the ITCV test are also shown. The interpretation of each of the columns in the table is analogous to that of the previous table but simply substituting the independent variable IPE for the variable OVER.

\section{Discussion}

The negative and significant relationship between the variable IPE and the HDI indicates that human development in European Union countries decreases as the rate of involuntary part-time employment increases (Model 4). This result corroborates Hypothesis 1 of our work, which states that involuntary part-time work restricts the expansion of human capabilities for people to lead the life they really want. Thus, employment quality is essential to value the action of working as a refined functioning insofar as it is chosen from among a set of possibilities [18-24]. In line with the theoretical approach of the HCA, involuntary part-time employment is not considered a refined functioning, since there is no other alternative but to choose this atypical employment; that is, there is no freedom to choose the achievement [30]. This underlines the importance of considering not only the quantity of employment in a given country in the analysis of human development, but also factors related to the quality of employment that allow us to determine the capabilities and functionings that individuals can generate [7].

Moreover, the negative and significant relationship between the variable OVER and HDI (Model 4) indicates that the HDI decreases as the rate of overcrowding increases in a country. This result corroborates Hypothesis 2, which states that when people live in overcrowded conditions, their capability to achieve their life goals is restricted. Thus, in line with the HCA, living in overcrowded housing adversely affects individuals' overall capabilities since it limits their basic instrumental freedoms, particularly protective security [49]. 
Finally, the variables EMP and EMI in Model 3 have a positive and significant effect on the HDI, thus indicating that an increase in both the employment rate and the percentage of migrants in a country increase the HDI. These results are in line with previous research that has shown a positive relationship between a country's economic development and an increase in labour market participation [51] as well as with studies that have found a link between the level of a country's well-being and higher migration to that country [50]. However, when Model 4 is estimated taking into account [52] the temporal and spatial dimensions, it can be seen that these variables [53] still have a positive impact on the HDI, but their coefficients are not statistically significant.

\section{Conclusions}

In this study, we measured the impact of employment quality and housing quality on human development. Under the hypothesis that involuntary part-time work and living in overcrowded conditions restricts people's capabilities to achieve the life they want, we examined the effects of the percentage of involuntarily part-time workers and the overcrowding rate on the HDI. To this end, a panel data model was specified for the period 2006-2018 using information from the 28 countries of the European Union.

The findings of this work have important implications for the implementation of public policies aimed at improving people's well-being, since they highlight some key elements of employment and housing that directly influence a country's human development.

This study demonstrated the limitations of measures or indicators of human development. Although the HDI since 1990 was calculated and provides a long series of observations, the index covers only three dimensions of quality of life. To address this issue, the results could have been compared with other quality of life indicators, such as the Social Progress Index (SPI). However, we were unable to use the SPI because it does not yet have a time series that is suitable for this type of study.

Taking into account this limitation, future lines of research could focus on the development of measures or synthetic indexes of quality of life based on indicators with historical series. This would enable us to further examine the impact of involuntary part-time work and overcrowding on people's quality of life using indicators beyond those measured by the HDI.

Author Contributions: Conceptualization M.C.-O., B.d.1.H.-R., R.C.-G.; methodology M.C.-O., B.d.1.H.-R., R.C.-G.; validation M.C.-O., B.d.1.H.-R., R.C.-G.; formal analysis M.C.-O., B.d.1.H.-R., R.C.-G.; investigation M.C.-O., B.d.1.H.-R., R.C.-G.; writing and editing M.C.-O., B.d.1.H.-R., R.C.-G. All authors have read and agreed to the published version of the manuscript.

Funding: This work was conducted within the framework of a research project FQM-150 and financed by Andalusia Government.

Institutional Review Board Statement: Not applicable.

Informed Consent Statement: Not applicable.

Data Availability Statement: The data presented in this study are openly available in EUROSTAT https: / /ec.europa.eu/eurostat/web/main/data/database and in UNDP data http:/ /hdr.undp.org/ en/data.

Conflicts of Interest: The authors declare no conflict of interest.

\section{References}

1. Ray, D.; Rabasco, M.E. Development Economics; Antoni Bosch: Long Island, NY, USA, 2002; ISBN 9788495348036.

2. Stiglitz, J.E.; Sen, A.; Fitoussi, J.-P. Report by the Commission on the Measurement of Economic Performance and Social Progress; Commission on the Measurement of Economic Performance and Social Progress: Paris, France, 2009.

3. Robeyns, I. Wellbeing, Freedom and Social Justice: The Capability Approach Re-Examined; Open Book Publishers: Cambridge, UK, 2017; ISBN 978-1-78374-421-3.

4. United Nations Development Program (UNDP). Human Development Report 2015: Work at the Service of Human Development; United Nations Development Program (UNDP): Washington DC, USA, 2015. 
5. Pavlopoulos, D.; Fouarge, D.; Muffels, R.; Vermunt, J.K. Who benefits from a job change: The dwarfs or the giants? Eur. Soc. 2014, 16, 299-319. [CrossRef]

6. Filandri, M.; Struffolino, E. Individual and household in-work poverty in Europe: Understanding the role of labor market characteristics. Eur. Soc. 2019, 21, 130-157. [CrossRef]

7. Sehnbruch, K. From the Quantity to the Quality of Employment: An Application of the Capability Approach to the Chilean Labour Market. Berkeley, USA. CLAS Work. Pap. 2004, 9, 1-66.

8. Andrews, F.M.; Withey, S.B. Social Indicators of Well-Being: Americans' Perceptions of Life Quality; Springer: New York, NY, USA, 1976.

9. Bauer, R. Social Indicators; M.I.T. Press: Cambridge, UK, 1966.

10. Michalos, A.C. Optimism in thirty countries over a decade. Soc. Indic. Res. 1988, 20, 177-180. [CrossRef]

11. Navarro, C. Housing and exclusion indicators. Soc. Doc. 2005, 138, 173-190.

12. Krause, N. Neighborhood deterioration and self-rated health in later life. Psychol. Aging 1996, 11, 342. [CrossRef] [PubMed]

13. Easterling, R. Building a better theory of well-being. IZA Discuss. Pap. Ser. 2003, 3, 742.

14. Cattaneo, M.; Galiani, S.; Gertler, P.; Martinez, S.; Titiunik, R. Housing, health and happiness. In Policy Research Working Paper; World Bank: Washington, DC, USA, 2007; p. 4214.

15. Keall, M.; Baker, M.G.; Howden-Chapman, P.; Cunningham, M.; Ormandy, D. Assessing housing quality and its impact on health, safety and sustainability. J. Epidemiol. Community Health 2010, 64, 765-771. [CrossRef] [PubMed]

16. Kuznets, S. Economic Growth and Income Inequality. Am. Econ. Rev. 1955, 45, 1-28.

17. Anand, S.; Sen, A. Human Development and Economic Sustainability. World Dev. 2000, 28, 2029-2049. [CrossRef]

18. Sen, A. Development as Freedom; Oxord University Press: New York, NY, USA, 1999; ISBN 9780375406195.

19. Sen, A. Employment, Technology, and Development; Oxford University Press: Oxford, UK, 1975.

20. Fukuda-Parr, S. The human development paradigm: Operationalizing Sen's ideas on capabilities. Fem. Econ. 2003, 9, 301-317. [CrossRef]

21. Sugden, R.; Sen, A. Commodities and Capabilities. Econ. J. 2006, 96, 820. [CrossRef]

22. Alkire, S. Why the Capability Approach? J. Hum. Dev. 2005, 6, 115-135. [CrossRef]

23. Anand, P.; Hunter, G.; Carter, I.; Dowding, K.; Guala, F.; Van Hees, M. The Development of Capability Indicators. J. Hum. Dev. Capab. 2009, 10, 125-152. [CrossRef]

24. Stewart, F.; Deneulin, S. Amartya Sen's contribution to development thinking. Stud. Comp. Int. Dev. 2002, 37, 61-70. [CrossRef]

25. Sen, A. Poverty and Famines: An Essay on Entitlement and Deprivation; Clarendon Press: Oxford, UK, 1981.

26. Leßmann, O.; Bonvin, J.M. Job-satisfaction in the Broader Framework of the Capability Approach. Manag. Rev. 2011, 22, 84-99. [CrossRef]

27. Leßmann, O. Applying the Capability Approach Empirically: An Overview with Special Attention to Labor. Manag. Rev. 2012, 23, 98-118. [CrossRef]

28. Gregory, M.; Salverda, W.; Bazen, S. Low Pay: An Analytical Perspective; Oxford University Press: Oxford, UK, 2000.

29. International Labour Organitation (ILO). Resolution of the 20th International Conference of Labor Statistics on Statistics on Employment Relationships; MEPICLS/2018; International Labour Organitation (ILO): Geneva, Switzerland, 2018.

30. Sen, A. Gender and Cooperative Conflicts; World Institute for Development Economics Research: Helsinki, Finland, 1987.

31. Office of the United Nations High Commissioner for Human Rights (ACNHUD). The Right to Adequate Housing; Fact Sheet No. 21/Rev.1; Office of the United Nations: Geneva, Switzerland, 2009.

32. Rindfuss, R.R.; Piotrowski, M.; Thongthai, V.; Prasartkul, P. Measuring housing quality in the absence of a monetized real estate market. Popul. Stud. 2007, 61, 35-52. [CrossRef]

33. Pan, Z. Housing quality differentials in urban China 1988-1995: Evidence from two national surveys. Int. J. Soc. Econ. 2003, 30, 1070-1083. [CrossRef]

34. Kutty, N.K. U.S. Housing: Determinants of Structural Adequacy and Crowding; Bronfenbrenner Life Course Center: New York, NY, USA, 1998.

35. European Commission. EUROSTAT, EU Labour Force Survey-Methodology; European Commission: Brussels, Belgium, 2020.

36. United Nations Development Program (UNDP). Report on Human Development. Human Development for All People; United Nations Development Program (UNDP): New York, NY, USA, 2016.

37. Dhahri, S.; Omri, A. Entrepreneurship contribution to the three pillars of sustainable development: What does the evidence really say? World Dev. 2018, 106, 64-77. [CrossRef]

38. Kangasharju, A.; Tavera, C.; Nijkamp, P. Regional Growth and Unemployment: The Validity of Okun's Law for the Finnish Regions. Spat. Econ. Anal. 2012, 7, 381-395. [CrossRef]

39. Gujarati, D.N.; Porter, D.C. Econometrics, 5th ed.; Mares Chacón, J., Zúñiga Gutiérrez, E.C., Eds.; McGraw-Hill/Interamericana Editores, S.A. de C.V.: Mexico, 2010; ISBN 9786071502940.

40. Wooldridge, J.M. Econometric Analysis of Cross Section and Panel Data; The MIT Press: Cambridge, UK, $2002 ;$ ISBN 0262232197.

41. Plümper, T.; Troeger, V.E.; Manow, P. Panel data analysis in comparative politics: Linking method to theory. Eur. J. Political Res. 2005, 44, 327-354.

42. Arellano, M.; Bover, O. Panel data econometrics. Res. Econ. (Segunda época) 1990, XIV, 3-45.

43. Baltagi, B. Econometric Analysis of Panel Data; John Wiley and Sons: Chichester, Inglaterra, 2005. 
44. Elhorst, J.P. Spatial panel data models. In Handbook of Applied Spatial Analysis: Software Tools, Methods and Applications; Fischer, M., Getis, A., Eds.; Springer Science \& Business Media: Berlin/Heidelberg, Germany, 2009.

45. Franck, K.A. Impact of a confounding variable on a regression coefficient. Sociol. Methods Res. 2000, 29, 147-194. [CrossRef]

46. Larcker, D.; Rusticus, T. On the use of instrumental variables in accounting research. J. Account. Econ. 2010, 49, 186-205. [CrossRef]

47. He, G.; Bai, L.; Ren, H. Analyst coverage and future stock price crash risk. J. Appl. Account. Res. 2019, 20, 63-77. [CrossRef]

48. He, G.; Ren, M.; Taffler, R. Do corporate insiders trade on future stock price crash risk? In Forthcoming at the Review of Quantitative Finance and Accounting; Springer: Berlin/Heidelberg, Germany, 2020; pp. 1-31.

49. Canarella, G.; Gasparyan, A. New insights into executive compensation and firm performance: Evidence from a panel of "new economy" firms, 1996-2002. Manag. Financ. 2008, 34, 537-554. [CrossRef]

50. Jönsson, K. Cross-sectional dependency and size distortion in a small-sample homogeneous panel data unit root test. Oxf. Bull. Econ. Stat. 2005, 67, 369-392. [CrossRef]

51. Beck, N.; Katz, J.N. What To Do (and Not to Do) with Time-Series Cross-Section Data. Am. Political Sci. Rev. 1995, 89, 634-647. [CrossRef]

52. Bartolucci, F.; Choudhry, M.T.; Marelli, E.; Signorelli, M. GDP dynamics and unemployment changes in developed and developing countries. Appl. Econ. 2018, 50, 3338-3356. [CrossRef]

53. Canales, A. Towards a comprehensive vision of the nexus between migration, development and human rights. Migr. Dev. 2011, $9,43-78$. 